\title{
Perception and Indicators of Climate Change, Its Impacts, Available Mitigation Strategies in Rice Growing Communities Adjoining Eastern Arc Mountains
}

\author{
Kashenge Sophia $^{1, *}$, Makoninde Emmanuel $^{2}$ \\ ${ }^{1}$ Agriculture Research Institute - Dakawa, Tanzania \\ ${ }^{2}$ Kilimanjaro Agriculture Training Center (KATC), Tanzania
}

Copyright $(2017$ by authors, all rights reserved. Authors agree that this article remains permanently open access under the terms of the Creative Commons Attribution License 4.0 International License

\begin{abstract}
Ongoing forest disturbances in the areas adjoining the Eastern Arc Mountains in Kilombero District associated with growing population and farm expansion led to increasing land degradation and fluctuations of hydrological supply downstream. This threatens not only biodiversity but also irrigated rice productivity. A structured Interview in conjunction with awareness creation was carried out in seven villages (Chita, Mbingu, Kisegese, Namawala, Mpofu, Njage and Mofu) to determine level of understanding among rice growers on the potential of these mountains for sustainable water flow downstream and the ability of farmers to detect and prepare towards impact of climate change. A total of 240 respondents (124 men and 116 women) were involved. Results revealed that, the whole concept of Eastern Arc Mountains and its potential for water availability in rice productivity as well as level of awareness on climate change, its impact, and preparedness reflected limited understanding. Awareness creation program was carried out involving 258 farmers (134 males and 124 Females). The study recommends a joint Eastern Arc Mountains conservation multi-stakeholder task force for preparation of a joint climate change mitigation and adaptation strategies. Furthermore, the study recommends introduction of agro forestry, promoting cocoa production and introduction of zero grazing among conservation measures.
\end{abstract}

Keywords Rice, Climate Change, Mitigation, Eastern Arc, Kilombero, Uzungwa Scarp

\section{Introduction}

\subsection{The Eastern Arc Mountains}

The Eastern Arc Mountains are a chain of mountains that run from the Taita hills of Hills in Kenya to the south-west of
Tanzania. According to TFCG [19], Eastern Arc Mountains originally encompass 23,700 sq. $\mathrm{km}$ and stretch in scattered mountain blocks from the Taita Hills in southern Kenya to the Udzungwa Mountains in southern Tanzania. The main mountains, from north to south, are: Taita Hills, North and South Pare, West and East Usambara, North and South Nguru, Ukaguru, Uluguru, Rubeho, and Udzungwa. These series of isolated mountains have been heavily covered by forests and are recognized as one of 34 globally important "hot spots" for forest biodiversity according to Conservation International [7]. Eastern Arc Forests are the oldest and most biologically diverse forests in the world. Most of the original forests, especially at the more accessible or lower elevations, have been utilized for agricultural production. The mountains are available in 14 Districts of Tanzania: South/North pare - Same and Mwanga Districts, East and West Usambara - Muheza, Lushoto and Korogwe Districts, Nguu - Kilindi District, Nguru - Mvomero District, Uluguru - Morogoro and Mvomero Districts, Ukaguru - Kilosa District, Rubeho - Mpwapwa and Kilosa Districts, Malundwe - Morogoro District, Udzungwa (the largest part) - Kilombero, Mufindi and Kilolo Districts and Mahenge - in Ulanga District.

Eastern Arc Mountains also serve as water catchments for urban areas such as Dar es Salaam, Tanga, and Morogoro, Tanzania. For example, Ruvu River comes from Uluguru Mountain; Pangani River partly comes from Pare, West Usambara and East Usambara Mountains; Sigi River comes from the East Usambara Mountains; Wami River comes from the Nguru, Ukaguru and Rubeho Mountains and the Great Ruaha and Kilombero Rivers that join the Rufiji come from Udzungwa Mountains. Rufiji, the largest river basin comprises of four major rivers, namely, the Great Ruaha River $\left(85,554 \mathrm{~km}^{2}\right)$, Kilombero River which crosses the major part of Kilombero District $\left(40,330 \mathrm{~km}^{2}\right)$, the Luwegu River $\left(25,288 \mathrm{~km}^{2}\right)$ and the Rufiji (lower part of Main River) [8, 14]. All these river basins make great contribution to rice productivity. 
Table 1. Location and areas of Eastern Arc Mountains

\begin{tabular}{|c|c|c|c|c|}
\hline Site & $\begin{array}{c}\text { Forest } \\
\text { Area } \\
\mathbf{( K m}^{\mathbf{2}} \mathbf{n}\end{array}$ & $\begin{array}{c}\text { Altitudinal } \\
\text { range of } \\
\text { forest }\end{array}$ & $\begin{array}{c}\text { Distance } \\
\text { from the } \\
\text { coast }\end{array}$ & $\begin{array}{c}\text { \% loss of } \\
\text { forest } \\
\text { cover }\end{array}$ \\
\hline Taita Hills & 3 & $1500-2140$ & 165 & 98 \\
\hline North Pare & 25 & $130-2113$ & 220 & 50 \\
\hline South Pare & 211.1 & $820-2463$ & 150 & 73 \\
\hline $\begin{array}{c}\text { West } \\
\text { Usambara }\end{array}$ & 220 & $1200-2200$ & 100 & 84 \\
\hline $\begin{array}{c}\text { East } \\
\text { Usambara }\end{array}$ & 450 & $130-1506$ & 50 & 57 \\
\hline Nguu & 140.42 & $1000-2250$ & 150 & - \\
\hline Nguru & 328.35 & $400-2000$ & 150 & 82 \\
\hline Ukaguru & 155.38 & $1500-2250$ & 220 & 90 \\
\hline Rubeho & 654 & $520-2050$ & 300 & 37 \\
\hline Uluguru & 291 & $1200-1275$ & 180 & 65 \\
\hline Malunwe Hill & 4.5 & $1200-1275$ & 270 & - \\
\hline Mahenge & 5 & $460-1040$ & 300 & 89 \\
\hline Udzungwa & 1017 & $300-2580$ & 300 & 76 \\
\hline
\end{tabular}

Source: Burgess et al., 2000

\subsection{Rice Production in Kilombero Basin}

More than $80 \%$ of the population in Kilombero District involved in Agriculture sector and Agriculture is their major source of income and food. Rice is the major crop grown for both cash and food followed by sugar cane as a cash crop. Other major food crops include maize, sweet potatoes, cassava, banana, legume, vegetables, fruits and coconuts. Cocoa, sesame and sunflower are also grown for cash in small areas. The district is divided into three major agro-ecological zones: eastern zone which has 28 villages lies along the part of Eastern Arc Mountains (the Udzungwa) and it is good for sugar cane and paddy production; the central zone which has 20 villages experienced flooding sometimes and it is good for paddy production and some livestock are kept. The western zone has 33 villages which are very potential for paddy, maize, banana and livestock production.

Kilombero is one of the major rice producing districts in Tanzania and largely depend on climate-sensitive sectors, such as rain-fed and irrigated agriculture; its fragile Eastern Arc Mountain ecosystems, dramatic topography and population pressure make the district more prone to extreme effects of climate change [13]. Higher temperatures and changes in precipitation patterns disrupt production systems in many ways such as changes in hydrological flow. The hydrological values of these mountains for irrigated rice productivity are currently imperative and need to be highly recognized by the respective rice growing communities adjacent to the mountains and further downstream. Ongoing forest disturbances, exploitation of natural resources associated with growing population and farm expansion have led to increasing pollution, fluctuations of hydrological supply and land degradation. The fluctuations of hydrological supply ultimately threaten not only biodiversity but also irrigated rice productivity, therefore causing destabilization of the community surrounding the mountains [13]. Furthermore, the extreme climate events including flooding, heavy rainfall, droughts, heat wave and cold stream are also on rise and are some of consequences of climate change [13, 15].

Rice growing communities need to recognize the relationship between climate at the Eastern Arc Mountains and their rice growing environment as useful ecosystem. Climate change impacts affect the ecosystem services that communities are largely dependent upon, threatening development and economic stability [1, 3]. Adaptation to climate change requires that farmers using natural resource and traditional techniques of agricultural production first to appreciate the existence of resources they are using and notice that the climate has altered, and therefore the alterations are anticipated on the resources they are using [16]. The level of information and knowledge on climate change impacts in several sectors of Tanzania is exceedingly patchy. Therefore, the aim of the project was to guarantee that rice production is sustainable, with minimal negative environmental impact, and copying with climate change. Furthermore, the study tried to assess the level of understanding of the potentials of Eastern Arc Nature Reserves in relation to sustainable water flow for rice production taking into account the ability of irrigated rice farmers in major rivers basins to detect climate change, to ascertain the increased vulnerability through nature reserve disturbances, and finally, understand the use of Indigenous Technical Knowledge (ITK) in climate change detection and responses.

\section{Methodology}

The study was conducted in selected seven villages located in five wards of Kilombero District, Morogoro region as indicated in Figure 1a \&1b. These villages adjoin Kilombero na Uzugwa scarp nature reserve. The villages and their respective wards in brackets are: Chita (Chita), Mbingu and Mpofu (Mbingu), Njage (Mchombe), Kisegese and Namawala (Idete), Mofu (Mofu) (Figure 2). Selection of the studied villages was purposeful because of their closeness to Eastern Arc Mountains which geographically favours agriculture particularly rice production in the area. The study employed a cross-sectional research design where both primary and secondary data were collected. Primary data involved both quantitative and qualitative data. The study sample was obtained by using simple random sampling technique from a sampling frame of rice farmers from the villages adjacent to Udzungwa Mountains. Moreover, key informants involved purposive selected village leaders, Village Agricultural Extension Officers and leaders from religious institutions. 


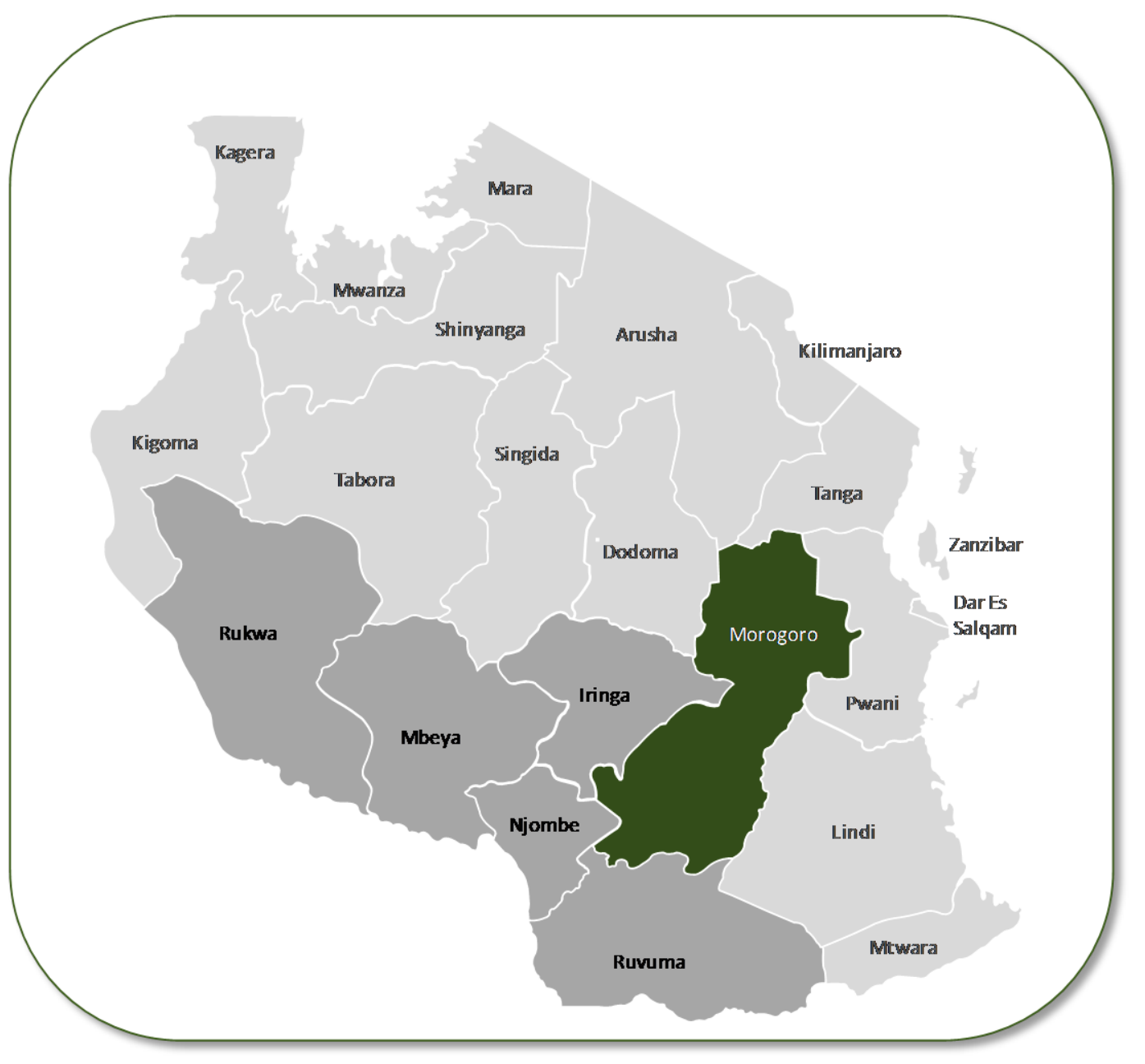

Figure 1a. Tanzania map showing Morogoro region

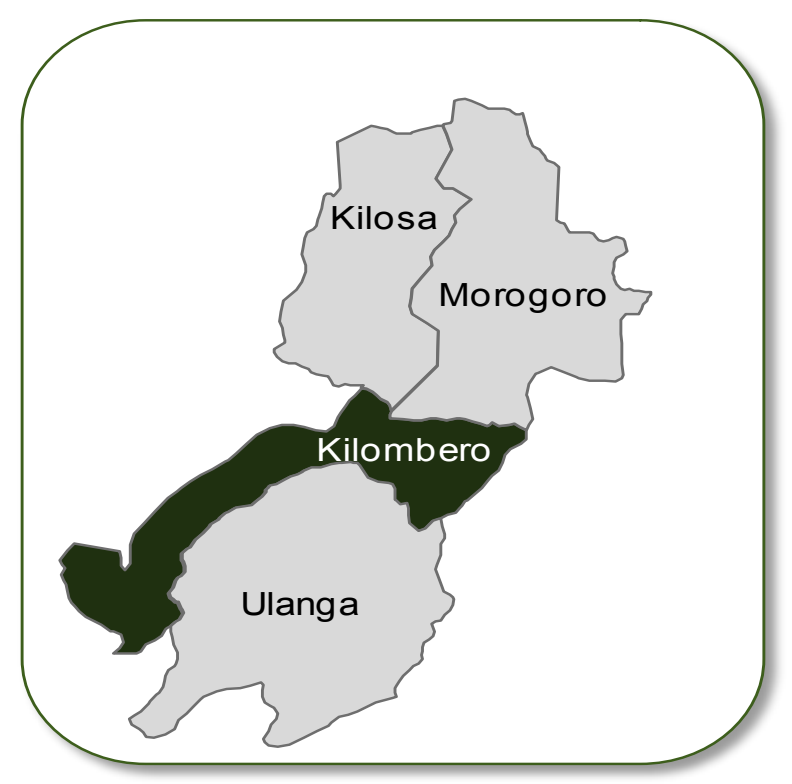

Figure 1b. Morogoro Region map showing Kilombero District 




Figure 2. Tanzania map showing the Eastern Arc chain of Mountains and location of the study villages

Methods in collecting qualitative data involved key informants interviews and focus group discussions. Structural interview was used to collect quantitative data. In collecting qualitative data, a check list of items for an in-depth interview with key informants was used to gather information from 28 key informants. A focus group interview guide was used in discussion to gather information from each of seven focus groups (one from each village). Secondary data were collected from various reports related to the study and the websites. To collect quantitative data, interviews were administered to a sample of 240 respondents (124 men and 116 women from all villages) to verify and quantify some of the findings from qualitative data. Finally, awareness creation was conducted by involving a total of 258 farmers (134 males and 124 Females) from all seven villages.

\section{Results}

\subsection{Rice a Major Source of Food and Income in Kilombero District}

Results confirmed that the majority (68.9\%) of farmers depend on rice cultivation for both food and cash. Furthermore, results also indicated that for the past 15 years $54.3 \%$ of respondents showed to have doubled their land for rice cultivation through either expanding their fields or opening a new land elsewhere. The average yields at district level remained low though increased from 1.9t/ha before 2012 to 3.2t/ha in 2016 (Kilombero District Agriculture Report, 2014). Generally, rice production showed to be increased during the period of almost 24 years $(1992-2016)$.
Yields tend to be increased with increasing area of production up to 2008's then from 2009 to 2016 a dramatic yield increase has been noted (Figure 3 ). The adoption of an improved variety (TXD 306 - SARO5) and associated good agronomic practices, increasing levels of intervention on improved technologies, farmers involvement as well as engagement of big companies such as KPL in rice production have been the reasons for the increased production and productivity in the district (Kilombero District Agriculture Report, 2016). However, only 27\% of the total respondents claimed to use mainly SARO 5 as an improved rice variety, the majority still use low yielding local varieties. The use of low yielding local rice varieties has also encourage opening up of new land up hills therefore increases forest destructions. Association studies also showed a significant positive correlation $\left(r=0.69^{*} ; \mathrm{p}<0.01\right)$ between yield increase and number of acreage of respondent.

Historically, people residing the valley had already developed original rice paddy cultivation system for subsistence farming by the mid nineteenth century. Since then, the system depends on run-off from flooded tributaries of different rivers originated mainly from Eastern Arc Mountains joining into the main Kilombero valley. The areas are highly fertile and reach in irrigation water due to availability of these chains of mountains covered by natural forests, this information was stated by $66 \%$ of the total respondents (Figure $4 \mathrm{a} \& \mathrm{~b}$ ). However, 78\%, 67\%, 54\%, 50\% $45 \%, 37 \%$ and $42 \%$ respondents from Chita, Mbingu, Mpofu, Njage, Kisegese, Namwawala and Mofu respectively admitted that they have determined to live in those villages due to the good agricultural environment, fertility and enabling agricultural weather condition. 


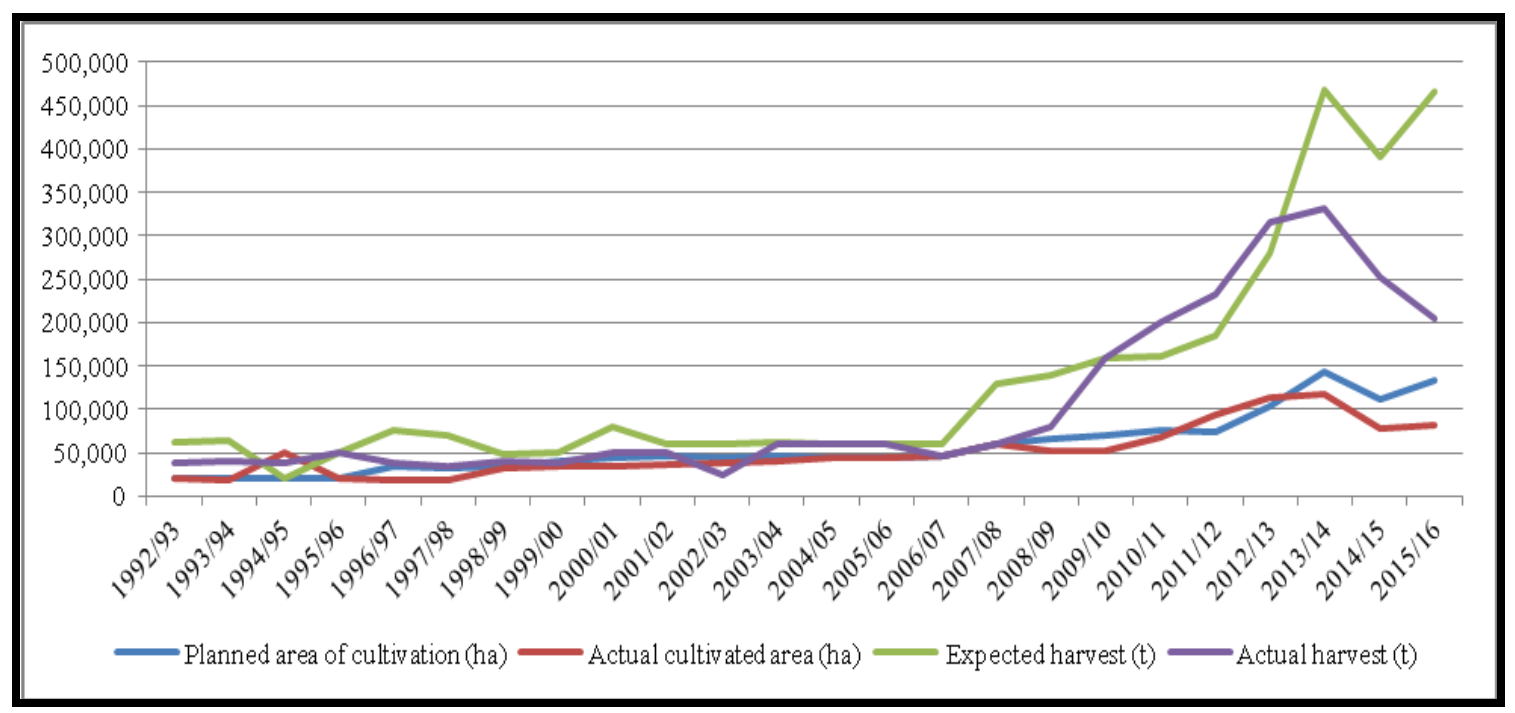

Figure 3. Rice cultivated areas and harvests from 1992-2016, (Source: Kilombero District Agriculture office, 2016)

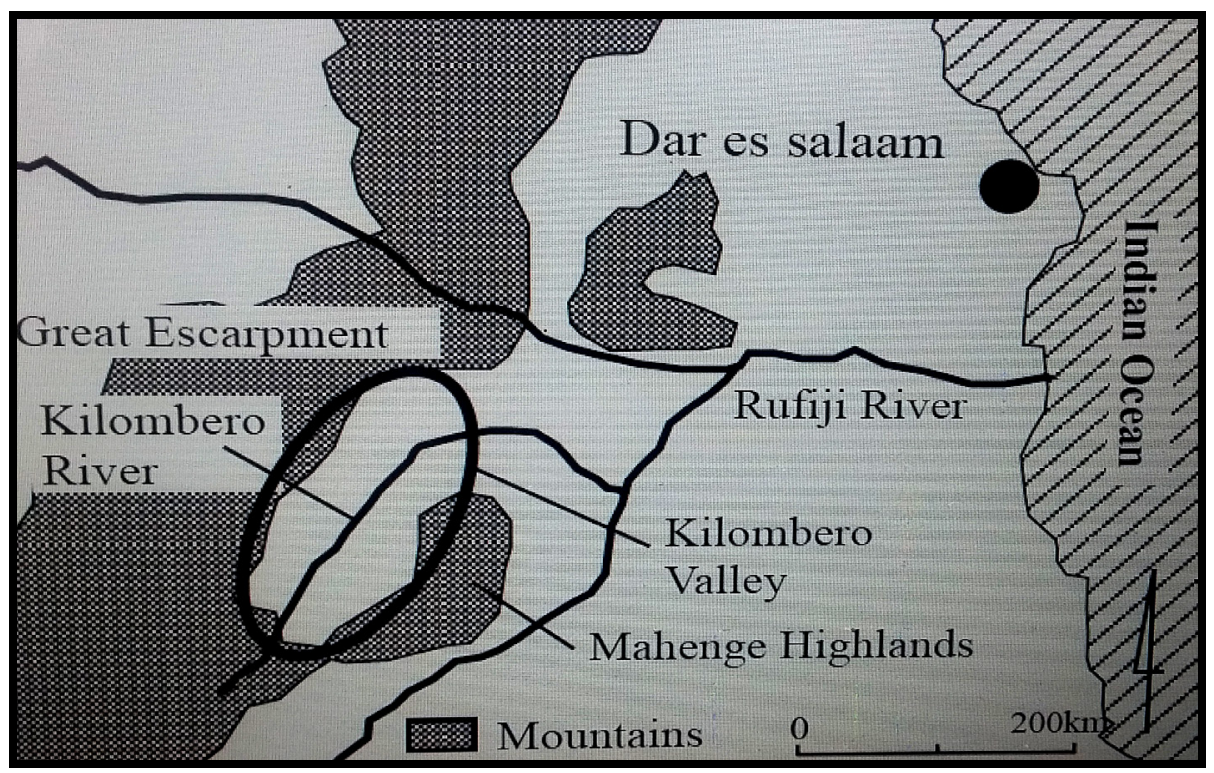

Figure 4a. Kilombero valley surrounded by a Great Escarpment of the Eastern Arc Mountains and also a part of great Rufiji River

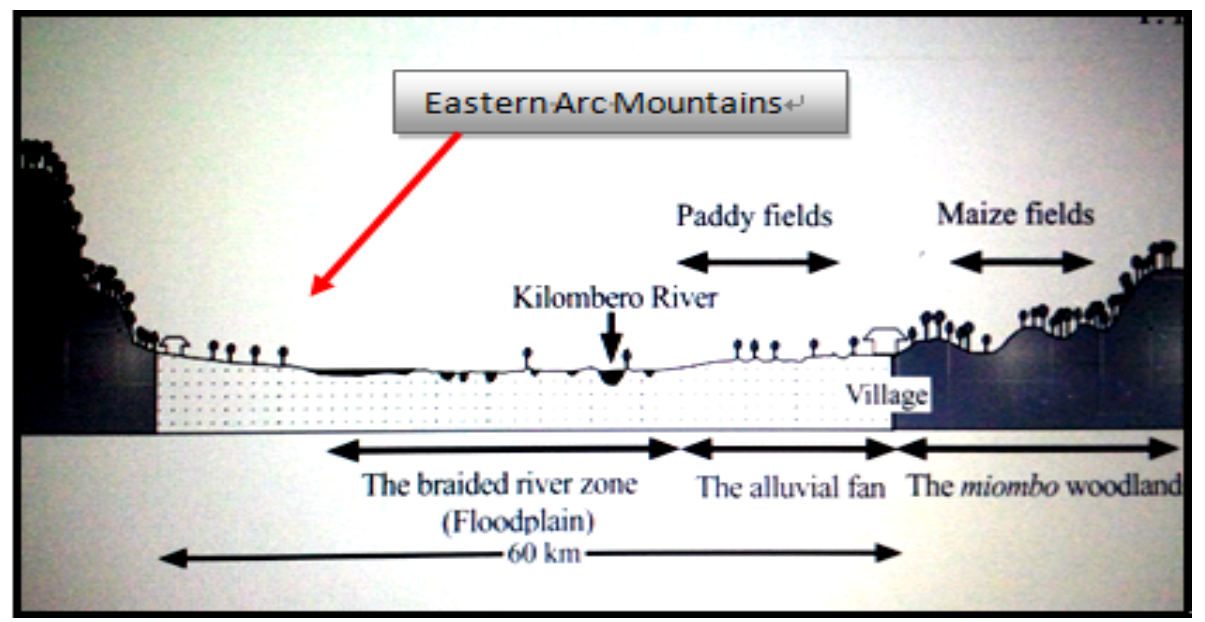

Figure 4b. A Typical profile of Kilombero valley. Source KATO (2007). 


\subsection{Potential Areas for Irrigated Rice Productivity}

More than $90 \%$ of rice farmers in the study area cultivate rice under low-land rain-fed agro-ecology. Results also have indicated the availability of potential areas for irrigated rice farms development whereby $98 \%$ of respondents urged that the areas for irrigated farm development is available and they would be happy to have irrigation scheme for more efficient production. According to the district Agriculture department report (2013), potential areas for irrigation in Kilombero District cover about 35,238 ha in total located in different villages. These include: Msolwa Ujamaa, Mkula, Sonjo, Kisawasawa, Sanje, Mang'ula , Mpanga, Kiberege, Signali, Kilama, Kisegese, Lumemo, Njage, Mgeta, Mkangawalo, Ikule, Udagaji, Idete, Mbingu, Lugongole, Sangasanga, Mofu, Machipi, Chita, Kihanzi, and Mpangala - Ngalimila valley.

Table 2. Potential areas for irrigation expansion in Kilombero District

\begin{tabular}{|c|c|c|}
\hline Name of Areas & $\begin{array}{c}\text { Potential areas for } \\
\text { irrigation (ha) }\end{array}$ & $\begin{array}{c}\text { Areas under } \\
\text { irrigation (ha) }\end{array}$ \\
\hline Msolwa(A) & 669.2 & 50 \\
\hline Mkula & 254.3 & 100 \\
\hline Njage & 325 & 75 \\
\hline Signali & 200 & 60 \\
\hline Kilama & 200 & 20 \\
\hline Ikule & 210 & 180 \\
\hline Makisonjo & 294 & 60 \\
\hline Udagaji & 200 & 12 \\
\hline Chita JKT & 12,000 & 60 \\
\hline Kisawasawa & 500 & 38 \\
\hline Kisegese & 210 & 10 \\
\hline Kihansi valley & 14,000 & 0 \\
\hline Total & $\mathbf{2 9 , 0 6 2 . 5}$ & $\mathbf{6 6 5}$ \\
\hline
\end{tabular}

Out of 35,238 ha only 9,532 ha are under cultivation, however, only 665 ha are cultivated by small scale farmer, the rest $(8,867 \mathrm{ha})$ are under large scale production mainly done by Kilombero Sugar (ILOVO) and Kilombero plantation Limited (KPL) companies. Therefore a huge potential area exists for rice production expansion under irrigated condition (Table 2).

\subsection{Agriculture Investments in Kilombero District}

Agriculture productivity is enhanced by availability of few investors acquired land and use for cultivation of different crops; these include Kilombero Plantation Limited (KPL), Rubada, Sugar Board of Tanzania (SBT) Kilimo Cha Yesu (KCY) and ILLOVO. The Kilombero Plantation Limited cultivates a total of 5,818 ha. The company cultivates soya beans (2,300 ha), the red beans ( $150 \mathrm{ha})$, Mug beans (150 ha) and pigeon peas (150 ha), the rest of area is under rice production. All these crops are cultivated during rainy season as a result of good climate around the area.
Rubada in collaboration with Kilombero District council (KDC) applied for land lease for 8,200 ha (5000 ha under large investment in Ngalimila and Ngombo villages and 3,200 ha at Merera and Chita villages). The district council in collaboration with Sugar board of Tanzania (SBT) is planning to establish new sugarcane crop plantation around the industry about 7,000ha will be used. Kilimo Cha Yesu is a private company found in Ngalimila village, Utengule ward, the company owns 180 ha suitable for maize and paddy production. Furthermore, Kilombero and Ulanga Districts in Morogoro region have the agronomic conditions suitable for Cocoa production. About 3000 ha are available for expanding cocoa production in area. All these efforts are due to enabling production and hydrological environment available in Kilombero valley.

\subsection{Exploitation of Natural Resources in Eastern Arc Mountains and Impacts in Rice Productivity}

A total of $76 \%$ of respondents in the study area declared that the population of Kilombero District is increasing for the past 10 years, and the situation leads to farm expansion that increase crop production in the district. On the other hand, few respondents $(14 \%)$ associated the increasing population with natural resource destruction upstream which has effects on water availability downstream. Again a small number $(10 \%)$ associated the increasing extreme weather events such as frequent floods and drought as well as the fluctuation of hydrological flow in almost all rivers in the district with the increasing population. However, the survey results declared that the use of some improved seeds and cultivation methods are among the reasons for farm expansion. According to $84 \%$ and $65 \%$ of total respondents, the use of farm tractors and herbicides for weed control respectively has a great contribution to farm expansion. This was supported by the association study which showed a strong positive correlation between education levels and use of tractors for farm preparation $(\mathrm{r}=0.45 ; \mathrm{P}<0.001)$ and the use of herbicides for weed control $(\mathrm{r}=0.72 ; \mathrm{P}<0.001)$.

\subsection{Rates of Migrant Affecting Environmental Conservation Measures}

A good number of respondents (55.8\%) associated forest destructions with the current increase in population resulted from immigrants. The situation increase demand pressure for agricultural land and building material from the forest. About $2-10 \%$ of the respondents in the studied villages moved in after securing areas for cultivation. A slightly high rate observed in Njage village where originally 20 ha were planned as a forest reserve area but an application was forwarded to responsible institutions so that more land can be used for crop production than forest reserve. Again, increased farmers migrant associated with livestock has also been mentioned by the majority (74\%) as among major reason that seriously affecting crop production in the area. 
Efforts to minimize number of livestock claimed to be minimum, inconsistent and un-sustainable increasing more challenges for food security.

\subsection{Climate Change: Increases Natural Resource Degradations and Constraining Rice Productivity}

A list of farmers production constraints were presented by respondents from each of the villages and consolidated in 12 major constraints (Figure 5). Four among 12 constrains were mentioned by more than $50 \%$ of respondent indicating the potential of these problems in the area. These are inadequate knowledge on impacts of climate change, un-predictable weather, low market price and low amount of rainfall in some years, and poor weather forecasting.

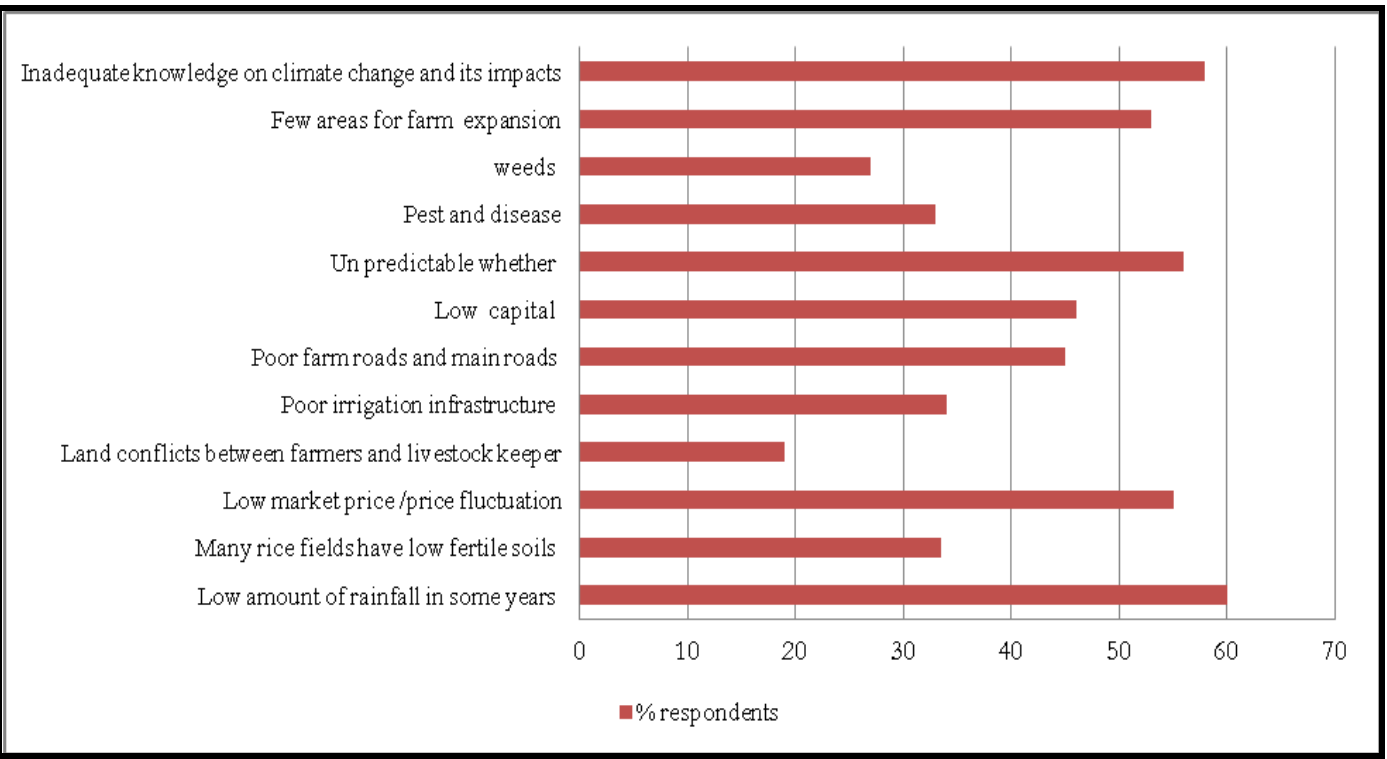

Figure 5. Major Rice production constraint in the study area

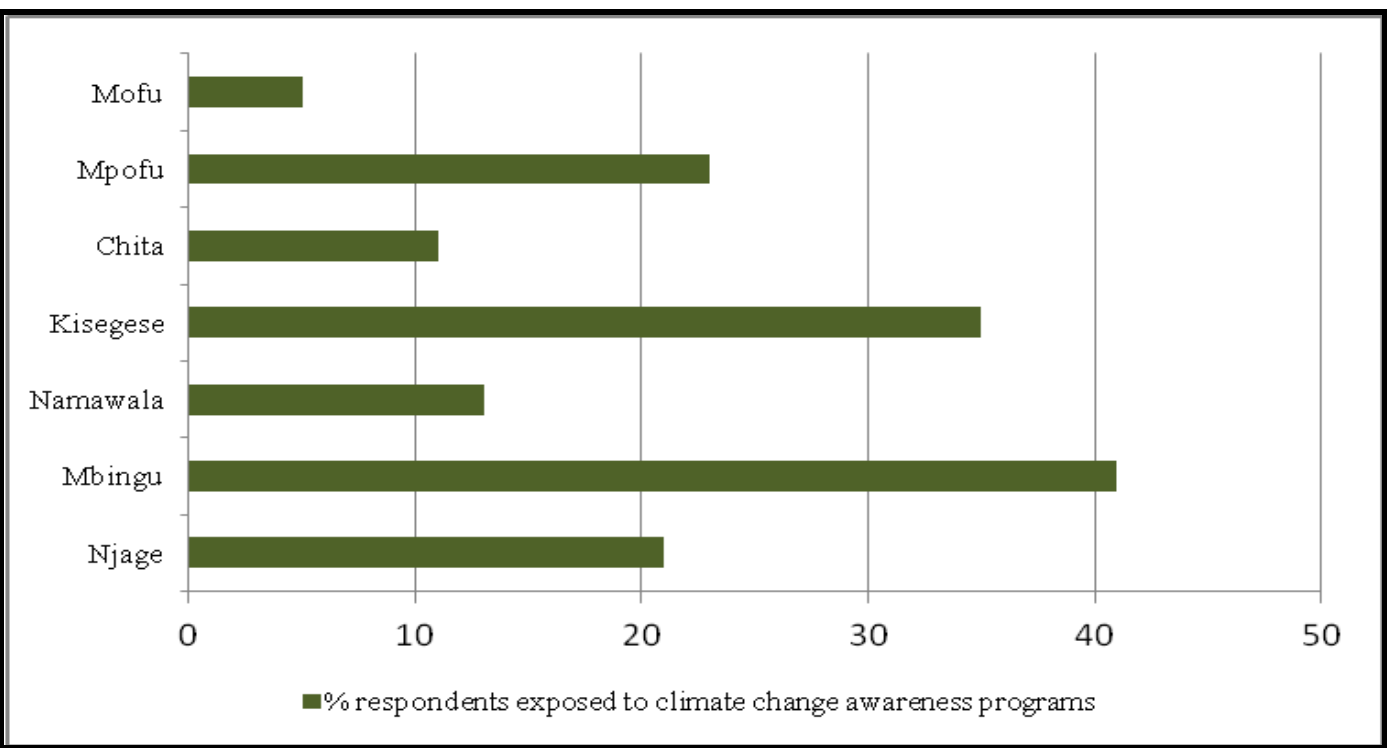

Figure 6. Percentage respondent exposed on climate change awareness program in six villages of Kilombero Districts 


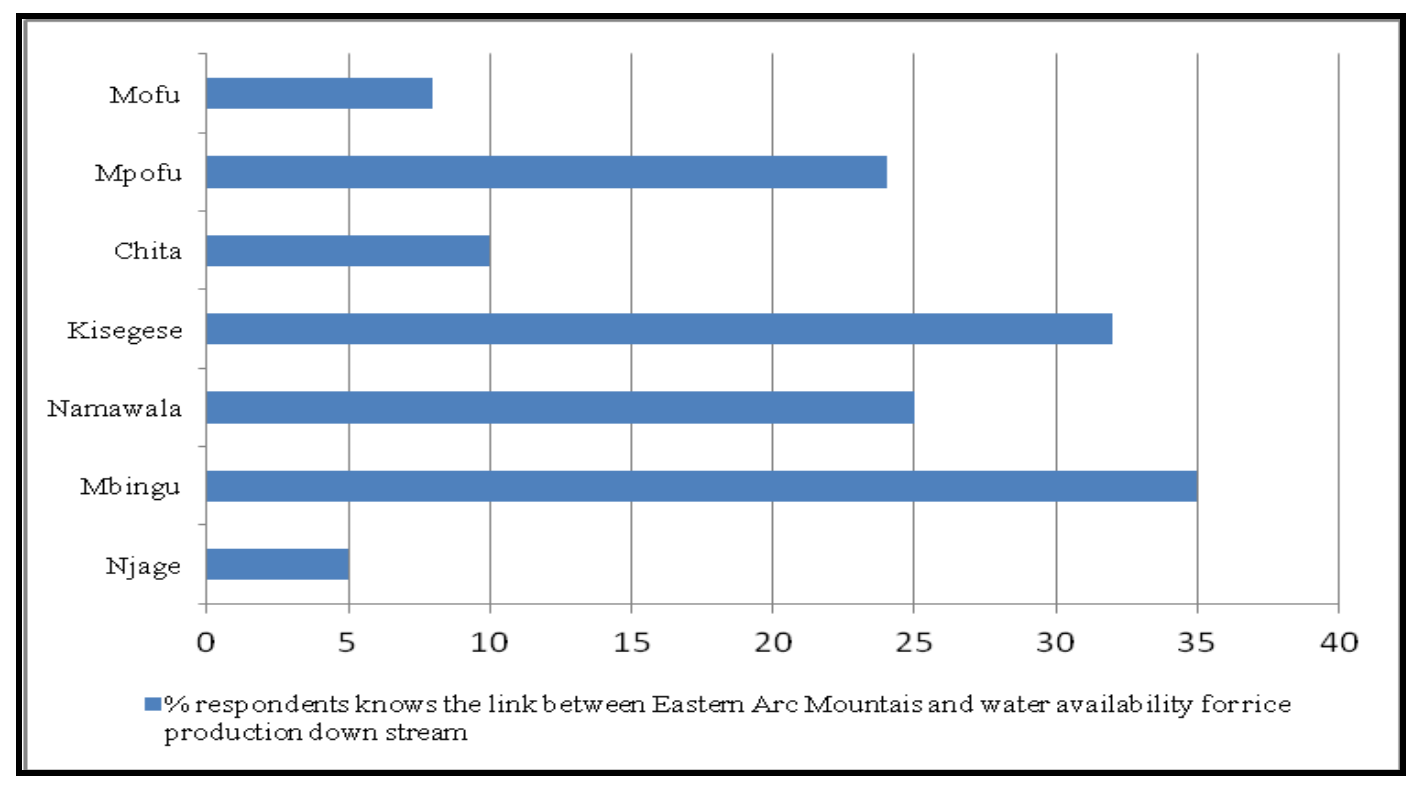

Figure 7. Percentage of respondents who knows the potential of Eastern Arc Mountains on availability of water for rice production

Climate change is real and farmers in all the surveyed villages have experienced its effects. Apart from factors constraining rice production in the area, some climate change indicators were mentioned more than the rest, these include: Unpredictable weather, increasing in temperature, shifting of rain seasons and lack of enough rainfall, mentioned by $67 \%, 70 \%, 88 \%$ and $100 \%$ of respondents respectively. Except for Chita village where $94 \%$ of respondent had experienced indicators of climate change, $100 \%$ of respondent from the rest of the villages had that experience at least one of these effects within the current 15 years. Average to low exposure on climate change information relatively to the number of institutions mentioned to conduct training programs in the selected villages were noted. Generally, less than $41 \%$ of respondents have been exposed on climate change awareness creation programs in all the villages (Figure 6).

\subsection{Awareness on the Potentials of Eastern Arc Mountains on Rice Production Down Stream}

Awareness on the potentials of Eastern Arc Mountains on availability of water for rice production was studied. The results revealed a minimum awareness, only $11-45 \%$ respondents are showed to be aware of the potential of Eastern Arc Mountains for availability of water in rice production (Figure 7), indicating the need for a serious awareness creation program in the surrounding communities. When asked if there is any link between forest destruction and increasing impacts of climate change, minimal number (less than 20\%) of respondent managed to establish a clear link although $81.8 \%$ claimed on the decreasing water levels in the surrounding rivers. These farmers ascertained expansion of cultivated land as the main reason for forest destructions and the main cause of inadequate water for both rice productivity and human consumption.

\subsection{Adoption Good Management Practices}

Education level plays a significant role in the adoption of new management practices as well as the improvement of environmental conservation. Correlation studies were performed to see the relationships among variables. The results revealed a slightly negative correlation $(r=-0.42$; $\mathrm{p}<0.01$ ) between education level of respondents and the need to have more land for field expansion. Similarly, a positive correlation $\left(\mathrm{r}=0.69^{*} ; \mathrm{p}<0.01\right)$ was also found between respondents' education and the use of Good Agriculture Practices (GAP). Furthermore, level of education correlates positively $(\mathrm{r}=0.52 * ; \mathrm{p}<0.01)$ with awareness of the potentials of Eastern Arc Mountain in the livelihood downstream. However, the study revealed that low number ( $2 \%$ to $7 \%$ ) of respondents exposed to good agriculture practices in rice production all the selected villages.

\subsection{Indigenous and Scientific Knowledge Indicating Disasters and Preparedness Measures to Climate Change.}

The study identified 10 different ITK practices indicating disaster scenarios associated to climate change. These practices were consolidated for all the villages and summarized in the Table 3 . The study also identified relevant climate change adaptation practices which were categorized into six major groups i.e. migration - particularly men in searching for new job and greener pasture or move to the areas with irrigation infrastructures, delay cropping, use of mixed cropping system, off-farm activities, digging wells and use of tolerant crop.

\subsection{Impact of Climate Change in the Eastern Arc Mountains}

The study assessed the attitude of respondents towards 
impacts of climate change in the Eastern Arc Mountains. When asked how they perceived the impact of climate change in agriculture and their livelihood in general, the majority $68.1 \%$ and $29.6 \%$ rated it as "bad" and "very bad" category respectively, which indicates their general concern of the problem. When asked what would happen to them in the absence of Eastern Arc Mountains, 34\% responded that lack of water will result in the long run and therefore no life (death). On the other hand, same respondents confessed that when protecting the mountains, wealth will result. Again when asked who should be responsible for financing adaptation measures, the majority of respondents (83.5\%) said that it should be the government. The study therefore noted very low community responsibility to adapt the impact of climate change.

Table 3. Scientific and indigenous technical knowledge and disaster adaptation measures

\begin{tabular}{|c|c|}
\hline \multicolumn{2}{|c|}{ Indication of Incoming disaster } \\
\hline Indigenous Knowledge & Scientific Knowledge \\
\hline $\begin{array}{l}\text { Appearing of some insects such as } \\
\text { army worms, birds such as Quelea } \\
\text { quelea and animals such as } \\
\text { Pangolon/Amadilo rats, snakes, } \\
\text { frogs and dragonfly }\end{array}$ & $\begin{array}{l}\text { Follow-up on the weather } \\
\text { forecast }\end{array}$ \\
\hline $\begin{array}{l}\text { Appearing of Stars and } \\
\text { constellation patterns at night }\end{array}$ & $\begin{array}{l}\text { Rise and fall of sea } \\
\text { temperatures }\end{array}$ \\
\hline $\begin{array}{l}\text { Some of tree species fail to flower } \\
\text { in a normal flowering period of time }\end{array}$ & Rainfall trends \\
\hline $\begin{array}{l}\text { Late rain season and changes on } \\
\text { weather pattern }\end{array}$ & $\begin{array}{l}\text { Follow-up on the weather } \\
\text { forecast }\end{array}$ \\
\hline \multicolumn{2}{|c|}{ Preparedness and adaptation measures strategies } \\
\hline Indigenous technical knowledge & Scientific knowledge \\
\hline $\begin{array}{l}\text { Changing of eating habits and } \\
\text { rationing the food }\end{array}$ & $\begin{array}{l}\text { Following of news and weather } \\
\text { forecasts }\end{array}$ \\
\hline $\begin{array}{l}\text { Farmers cultivate short duration or } \\
\text { drought-tolerant types of crop } \\
\text { species. Many prefer the use of } \\
\text { local grains such as millets and } \\
\text { sorghums that are more drought } \\
\text { tolerant than maize varieties, as well } \\
\text { as the use of tuber crops such as } \\
\text { cassava and sweet potatoes }\end{array}$ & $\begin{array}{l}\text { Encourage the use of drought } \\
\text { tolerant varieties as well as } \\
\text { short duration crops }\end{array}$ \\
\hline $\begin{array}{l}\text { Practicing mixed cropping. A } \\
\text { diversity of crop types and varieties } \\
\text { are grown ether in the same field of } \\
\text { in rotation, this spreads the risk of } \\
\text { losing an entire year's production }\end{array}$ & Observe livestock stocking rate \\
\hline
\end{tabular}

\subsection{Sector Involvement in Adaptation Measures}

Respondents were asked if "they saw involvement of any sector in mitigating climate change impacts" to which only $35 \%$ replied "yes". When asked whether or not they have made any personal changes in response to climate change impacts, only few 5\% responded "yes" and $78 \%$ responded "no". However, there was a widespread willingness to adopt various measures to reduce the vulnerability. The majority, $65.5 \%$ chose "education on good agriculture practices to increase production per unit area in order to minimize forest degradation, and $35.5 \%$ requested on the use of agro-forest to minimize land clearing as well as provision of alternative cash crop.

\subsection{Institutions Involvement in Climate Change Awareness Programs}

Institutional analysis (Figure 8) showed a list of different organizations involved in different awareness creation programs on climate change and mitigation, soil and forest conservation as well as tree nursery establishment. These include Kilombero Valley Development Organisation (KIVEDO) - mentioned by $45 \%$ of respondents, Universities - Sokoine (SUA) and Dar-es Salaam (UDSM) 20\%, Tanzania National Park (TANAPA) - 15\%, World Life Fund for nature (WWF) - 17\%, COEL Tanzania limited - 7\%, Tanzania Forest Conservation Group (TFCG) - 25\%, Agriculture Research Institute (KATRIN) - 10\% of respondents, Eastern Arc Mountain Conservation Endowment Fund (EAMCEF) - 7\%, District Council - 5\% as well as Association of Kilombero High Quality Rice Grower (AKIRIGO) mentioned by $2 \%$ of participants. None of these institutions has been mentioned by $50 \%$ of the respondents indicating lack of a strong awareness creation programs apart from the effort showed by KIVEDO. This also indicated inadequate in-depth exposure to forest conservation information which again reflected by low level of awareness on the potential of Eastern Arc Mountains in the livelihood of the people surrounding these mountains. This was supported by good number of respondents $46.6 \%$ claimed not to have heard of the word Eastern Arc Mountains despite of residing at the foot of these mountains.

\subsection{Project Awareness Training Program}

Public awareness is important to increase enthusiasm and support, stimulate self-mobilization and action, and mobilize local knowledge and resources. EAMCEF - ARI - KATRIN rice project carried out an awareness training program in six (6) EAMCEF intervention and one (1) none intervention villages to help farmers understand the hydrological potential of the Eastern Arc Mountains, effects of forest destruction and increasing effects of climate change which ultimately affect water availability for rice production downstream. The training involved a total of 560 farmers (336 Male and 224 females) (Figure 9). Among others, the aim of awareness raising program includes increasing concern on the ongoing natural resource destructions, and creating a positive image and attempt to change their behavior towards natural forest resource management. Results indicated that more people than planned attended the training program. 




Figure 8. Institutions participating in forest conservation and climate change awareness program in the project intervention villages

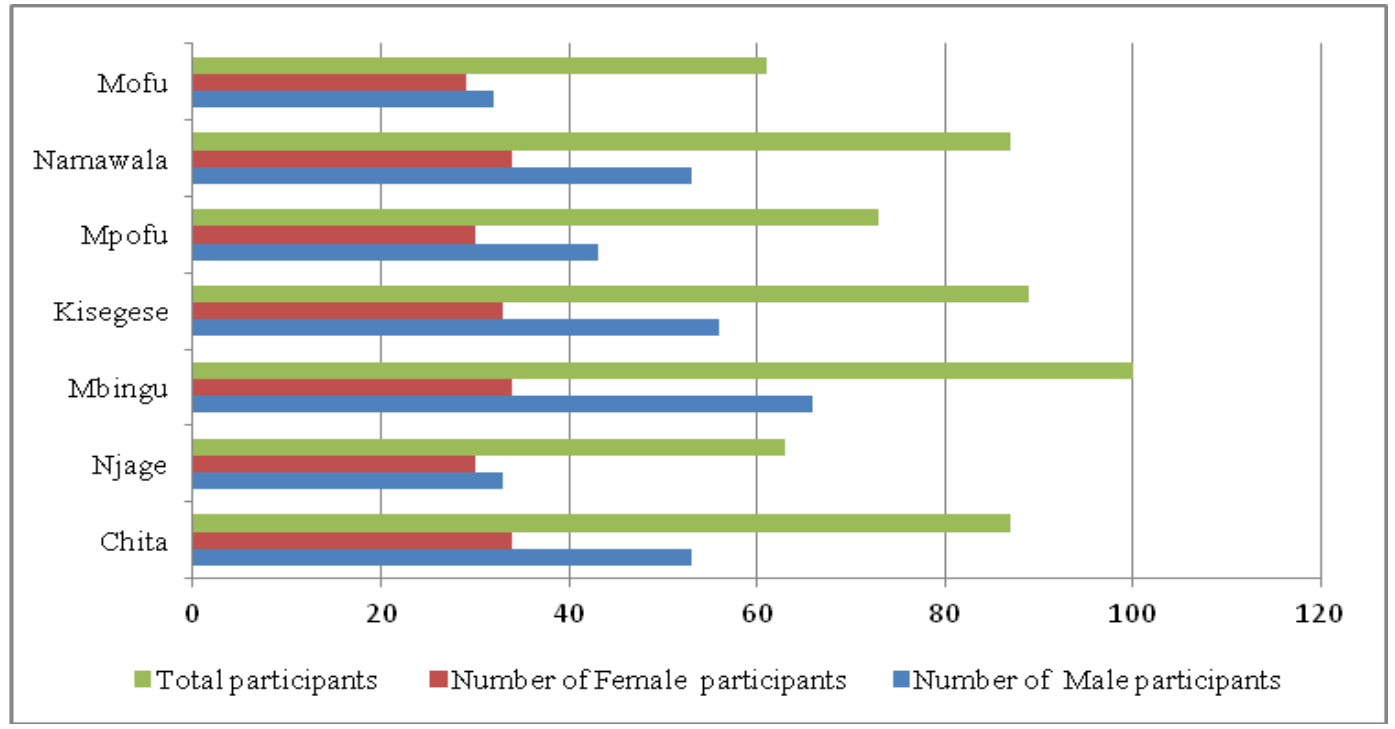

Figure 9. Number of participants in the training program

\section{Discussion}

The study revealed that the Eastern Arc Mountains contributes to the economy of the Kilombero District, Morogoro region and the country at large due to high rainfall, good climate and fertile soils. Similar findings have been reported [17, 23] that densely forested Kilombero and Uzungwa scarp nature reserves contributes enormously not only on Tanzania's southern highlands agriculture economy but also on countries biodiversity with a range of unique endemic species. Besides this biological importance, the forests are crucial as a water catchment to most of the rivers in Kilombero District and beyond. They also contribute significantly as the source of vast volumes of water utilized in hydro-electric power generation and irrigation [11]. The reported increasing population in these study areas contributes significantly in increasing exploitation of the natural resources in the surrounding Eastern Arc Mountains therefore threatening the existing biodiversity. Similar results has indicated that exploitation of natural resources associated with growing population has led to increasing pollution, declining water quality and land degradation, resulting into increasing the events of climate change in mountainous areas $[1,20]$.

Kilombero Valley, partly surrounded by the Eastern Arc Mountains holds some of the most fertile lands of Tanzania. This attracts both agriculturalist and pastoralists in the area therefore increasing population of both animals and people hence, rising land degradation activities. Results of this study are in agreement with a report that internal population 
growth and the influx of people from different areas have created an increased demand for food, and therefore the use of wetland resources has increased and intensified over the past few decades [20]. The study also concurs with the findings that the increasing in uncontrolled both subsistence farming and the continued expansion of commercial agriculture ventures increase a threat on stability of the ecosystem which also increase conflict of interest between environmental conservation and the livelihoods of local communities [11].

Rice production is a key crop cultivated across the Kilombero District, both as a food crop and a cash crop, making it a high volume contributor to total national rice production [2]. According to Rice Assessment \& Sector Strategy report (2011), Kilombero District has a high production potential making Morogoro region a major rice producing region in rice growing areas of Tanzania. According to the District Agriculture department report (2013), rice cultivation in Kilombero is expanding rapidly as a source of income, and several new production areas are formed these results are also in line with the findings of this study as reflected in figure 3 showing rice production trends for 22 years in Kilombero District. Among the reasons why rice production has successfully increased are the introduction of improved knowledge and skills in rice production, improved technologies such as rice varieties and management practices and the use of tractors and trucks. In this regard, production using the improved cultivation system has increased. Suitable lands for the flood cultivation system become limited therefore farmers increase cultivation in the narrow riversides therefore ultimately increasing land degradation and forest destructions in the surrounding mountains.

According to SAGCOT report (2004) the current low input, low output, low technology, low risk traditional farming systems used by about $90 \%$ of Tanzania's farmers leave them highly vulnerable to climate change. Farmers are not well informed or well organized. They still make little use of irrigation, improved seeds or basic mechanization. Soil and water conservation techniques are not often applied, in addition their market options are therefore limited [22]. This concurs with the findings of this study which indicated a negative correlation between education level of respondents and the need to have more land for field expansion, signifying that more educated people can make smaller land area more productive than none educated. Again a positive correlation between education level and awareness of the potentials of Eastern Arc Mountain in the livelihood downstream indicated that education level play a significant role in adoption new management practices as well as improvement of environmental conservation. This was clearly reflected in increased production from 2010-2016 (figure 3), whereby increased interventions done in the area and engagement of large companies in rice production using highly improved technologies make significant increase in yields. Increasing the availability of irrigation schemes is among strategies to improve production and productivity in the district. Furthermore, enhanced knowledge on climate change and their mitigation to farmers will have an increased impact on management of natural resources, increased preparedness during disasters and intensifying production, therefore increase production and productivity of rice and minimum land expansion in the area.

A result from similar studies indicates that climate change impact model projected rice yield will roughly double between 2010 and 2050 [12]. With a small increase in area, the production of rice will slightly increase more than twice. The study went further that with such a rapidly growing population, production will not keep up with demand, and imports of rice will rise. The analysis also projected that the international price for rice will increase by 55 percent between 2010 and 2050 [12]. Therefore, intensification in production using small available land through enhancing farmers' knowledge on better production techniques and nature conservations are among the urgent strategies [22]. It is clear that, no matter what changes will happen; Tanzanian farmers must be ready for the unknown, and able to provide their own responses. The report therefore suggested two elements to the response: first, increased awareness and improved information systems and second, better resilience to changing conditions and preparation for adaptation [3, 5 \& 17]

Studies reported further that the increase in land degradation and forest destructions from East Usambara, Uluguru and Udzungwa as part of Eastern Arc Mountains and the climate of these mountains have become drier and warmer over this century. Rivers volume shrinks with time and in addition, farmers' perception and information on the changes and their effects on livelihood of the people are very limited. The report went further that, this has a lot of effects on the community depending on these mountains for their day to day activities [10]. Similarly, the finding of this project has reported that perceptions and knowledge regarding changes in climate are of paramount importance in understanding the nature and resource changes as well as preparedness for mitigation.

Again, it has been reported that the "readiness" to cope with the impacts correlate with the level of economic and human development, as well as with the level of knowledge and information on climate change, therefore perception and awareness are necessary prerequisite for adaptation $[9,18]$. In addition, the use of indigenous technologies has been among the useful measures to cope with impact of climate change. Indigenous Technical knowledge (ITK) is an ancient, communal, holistic and spiritual knowledge that encompasses every aspect of human existence [21]. This knowledge has been used differently in communities as indicator and/or predictors of incidences that may happen. The study identified different ITK techniques used by local communities in the study areas that used as a way to detect and prepare with the climate change effects. Reports showed 
that local communities through accumulated ITK gained from generation to generation knew patterns of weather, how and when local natural disasters occur, when they were likely to recur, how to plan to cope with their impacts on the natural environment, livelihoods and lives. The use of combined ITK and scientific knowledge can help to enhance farmers' knowledge, preparedness and resilience to climate change. This has also been reported in similar studies [18]

\section{Conclusions and Recommendations}

The study was carried out in order to make sure that rice production is sustainably increased under a minimal negative environmental impact, and copying with the increasing effects of climate change in areas adjacent to Eastern Arc Nature Reserves in Kilombero District. This was done through assessment on the level of understanding of the potentials of Eastern Arc Nature Reserves in relation to the sustainable water flow for rice productivity, the ability of farmers to detect climate change, and to ascertain the increased vulnerability through nature reserve disturbances, understand the use of Indigenous Technical Knowledge (ITK) in climate change detection and responses and finally enhance farmers' knowledge on climate change and their mitigation in order to increase management of natural resources and the increased preparedness during disasters and intensifying rice production.

Generally, Kilombero District is partly surrounded by The Eastern Arc Mountains, which enables the district to have a very good climate that highly attracts agricultural activities. It will therefore increase internal population growth and the influx of people from different areas. The population growth goes together with the increasing exploitation of natural resources, a serious expansion of farm land resulting into among other challenges, declining water availability and quality especially for rice production that affecting livelihood of the people downstream, contributing to nature and biodiversity loss and increasing land degradation that contributes to the increasing events of climate change.

Famers' knowledge and understanding on Eastern Arc Mountain (Milima ya Tao la Mashariki) and its link in the availability of water for rice production downstream are very low. This shows that joint efforts have to be made to make sure that these mountains and their potentials for biodiversity and livelihoods of the people downstream are well known to the majority for better forest conservation of these mountains and increased agriculture productivity. Generally, the low exposure to climate change information and low level of awareness on the potential of Eastern Arc Mountains in rice productivity among participants and among villagers in all represented villages bring to light the general indication that awareness creations efforts are very minimal. However, when given a chance, farmers are able to develop adaptation strategies both conservation and non-conservation. Therefore, strong efforts have to be made to raise awareness of climate change and its impact on the society, environmental conservation, the potentials for the Eastern Arc Mountains, as well as the importance of these mountains in availability of irrigation water for rice farmers downstream. It was further concluded that Eastern Arc Mountains are the sources of livelihood for rice growing community adjacent to it and when other factors remains constant; "No Eastern Arc, No rice production, hence No Life".

The study therefore recommended a sustainable awareness creation program on climate change and their mitigation to increase management of natural resources, increased preparedness during disasters and intensifying rice production. In addition, development of a joint Eastern Arc Mountains conservation multi stakeholder task force which comprises nature conservation managers, agriculture officers, farmers' representatives, extension offices, and different institutions involved in environmental conservation as well as preparation of a joint mitigation and adaptation strategy specifically for Kilombero valley is therefore suggested. This will ensure that the forest natural resource upstream rice productivity downstream continuum operates smoothly and for the benefit of all. Furthermore, introduction of agro forestry as alternative source of wood fuel and promotion of cocoa plantations as an alternative cash crop is very essential in order to boost farmers' income. Finally, promotion of zero grazing system to increase nature conservations, protection of existing wetlands and promotion of the use of biogas instead of wood fuel is also recommended.

\section{Acknowledgements}

This study was made possible by a grant from The Eastern Arc Mountains Conservation Endowment Fund through Agriculture Research Institute (ARI) KATRIN and Chollima Agro-Scientific Research Centre - Dakawa. The authors wish to thank the management and all the staffs of the ARI and MATI- KATRIN for their support. Special thanks to Mohamed Mmanga, Benjamin Mfupe, Abdalah Mpunga, Juliana Mangu, Juma Wenelah and Zainab Changalima for provision of some of the data and ideas contained in this paper. Many thanks are extended to ARI - KATRIN drivers, extension staffs and village leaders from all seven villages for their useful information and support.

\section{REFERENCES}

[1] Agrawala, S. and M. Berg. 2002. Development and Climate Change Project: Concept Paper on Scope and Criteria for Case Study selection. com/env/epoc/dcd/dac1/final, OECD, Paris. (Accessed in March 2013)

[2] AGRA - Allience for Green Revolution in Africa. 2011. Tanzania Bread-Basket Transformation Project-District 
Profiles.

www.kilimo.go.tz/...TBBT\%20Project_Annex\%20A_District \%20Profile (Accessed in March 2013)

[3] Boko, M., A. Niang, A. Nyong, C. Vogel, M. Githeko, M. Mednay, B. Osman-Elasha, R. Tabo, and P. Yanda. 2007. Africa. In Climate Change 2007: Impacts, Adaptation and Vulnerability. Contribution of Working Group II to the Fourth Assessment Report of the Intergovernmental Panel on Climate Change, ed. M. L. Parry, J. P. Canziani, J. P. Palutikof, P. J. van der Linden, and C. E. Hanson. Cambridge: Cambridge University Press.

[4] Burgess, N. D., T.M. Butynski, N.J. Cordeiro, N.H. Doggart, J. Fjeldså, K.M. Howell, F.B. Kilahama, S.P. Loader, J.C. Lovett, B. Mbilinyi, M. Menegon, D.C. Moyer, E. Nashanda, A. Perkin, F. Rovero, W.T. Stanley and S.N. Stuart. 2007. The biological importance of the Eastern Arc Mountains of Tanzania and Kenya. Biological Conservation 134: 209-231.

[5] Burgess, N.D. and G.P. Clarke. 2000. The Coastal Forests of Eastern Africa. The IUCN Forest

[6] Burgess, N.D., G.P. Clarke, J. Madgewick, S.A. Robertson and A. Dickinsen. 2000. Distribution and Status. In The Coastal Forests of Eastern Africa. N.D. Burgess and G.P. Clarke, eds. IUCN: Cambridge and Gland. Pp. 71-81.

[7] Burgess, N.D., S. Madoffe, G. Kajembe, R. Trevelyan and A. Perkin .2010. Are invasive plant species a problem in the Eastern Arc Mountains? The Arc Journal 25: 23-26.

[8] Burgess, N.N., M. Nummelin, J. Fjeldså, K.M. Howell, K. Lukumbyzya, L. Mhando, P. Phillipson and Vanden Wege, J.P. (eds.) 1998a. Biodiversity and Conservation of the Eastern Arc Mountains of Tanzania and Kenya. Special Issue: Journal of the East African Natural History Society 87: 1-367.

[9] Case, M. 2006. Climate Change Impacts on East Africa. A Review of the Scientific Literature. WWF-World Wide Fund for Nature (formerly World Wildlife Fund), Gland, Switzerland.

[10] Hamilton, A. 1998. Vegetation, climate and soil: altitudinal relationships on the East Usambara Mountains. Journal of the East African Natural History Society 87: 85-90

[11] Hurrison, P. 2006. Socio-Economic Study of Forest-Adjacent Communities from Nyanganje Forest to Udzungwa Scarp: A Potential Wildlife Corridor. Incorporating Livelihood Assessments and Options for Future Management of Udzungwa Forests. WWF Tanzania Programme Office and Critical Ecosystem Partnership Fund (CEPF) Bankipore House, High Street, Brill, Bucks HP18 9ST, UK
[12] Kilembe, C., Thomas, T.S., Waithaka, M., Kyotalimye, M., Tumbo, S. 2012. International Food Policy Research Institute. East African Agriculture and Climate Change: A comprehensive analysis - Tanzania Report

[13] Kisanga, D. R. 2005. Tradition and science: Environmental change on east African Mountains. Geography Department at Miami University, Middletown, Ohio, USA.

[14] Lovett, J.C. 1998a. Importance of the Eastern Arc Mountains for vascular plants. Journal of the East African Natural History Society 87: 59-74.

[15] Lovett, J.C., G.F. Midgely, P.B. Barnard. 2005. Climate change and ecology in Africa. African Journal of Ecology 43: 279-281.

[16] Maddison, D. 2007. The Perception of and Adaptation to Climate Change in Africa. Policy search working paper 4308. The World Bank Development Research Group. Sustainable Rural and urban Development Team.

[17] Moyer, D. 1992. Report on the natural resources consultancy for the Udzungwa Forest Management Plan Project Preparation Mission. Forest and Beekeeping Division/DANIDA, Dar es Salaam.

[18] Myers, N., Mittermeier, R.A., Mittermeier, C.G., da Fonseca, G.A.B., Kent, J. 2000. Biodiversity hotspots for conservation priorities. Nature 403: 853-858.

[19] TFCG. 2009. Tanzania Forest Conservation Group[http://www.tfcg.org/docs/about_us.htm]

[20] Kangalawe, R. Y. and E. T. Liwega. 2005. Livelihoods in the Wetlands of Kilombero Valley in Tanzania: Opportunities and Challenges to Integrated Water Resource Management. Physics and Chemistry of the Earth, Volume 30, pp. 968-975

[21] Brascoupe, S. and H. Mann. 2001. A Community Guide to Protecting Indigenous Knowledge. Ottawa, ON: Indian and Northern Affairs Canada

[22] Chabwera M and J. Macgregor .2009. Cultivating success: the need to climate-proof Tanzanian Agriculture. IIED Briefing

[23] Hochkirch, A. 2010. Niche conservatism among allopatric species of the grasshopper genus Afrophlaeoba Jago, in the Eastern Arc Mountains (Tanzania). In J.C. Habel \& T. Assmann (eds.), Relict Species-Phylogeography and Conservation Biology. Springer, Berlin. Pp. 145-158.

[24] Kato, F. 2007. Development of a major rice cultivation area in the Kilombero valley, Tanzania. African Study Monographs, Suppl.36: 3-18 